\title{
Project Management Problems in Small and Medium Enterprises in Nigeria
}

\section{Carl Osunde}

Dean of Studies, Onitsha Business School, Anambra State, Nigeria

"Corresponding author: Carl Osunde, Dean of Studies, Onitsha Business School, Anambra State, 19A Regina Nwankwu Avenue, G.R.A, Onitsha, Nigeria, Tel: +2348169783063; E-mail: osundecj@gmail.com

Received date: November 24, 2015, Accepted date: January 28, 2016, Published date: February 03, 2016

Copyright: (c) 2016 Carl O. This is an open-access article distributed under the terms of the Creative Commons Attribution License, which permits unrestricted use, distribution, and reproduction in any medium, provided the original author and source are credited.

\begin{abstract}
SMEs engage in projects which includes innovations, new product development, product improvement and implementations of new processing technology. SMEs in Nigeria face challenges that hinder their projects such as Organizational Structure, Finance, Project Management Knowledge and Environment. This research examines the problems that confront SMEs to effectively manage projects. The research also examines the relationship between failures of SMEs and undertaken SMEs projects in Nigeria and proffers solutions to surmount the associated problems failures of SMEs and their undertaken projects.
\end{abstract}

Keywords: Project; Small and medium enterprises; Management; Entrepreneurship; Organizational structure

\section{Introduction}

Small Scale Enterprises are very crucial to the development of a country's economy, especially countries like China, India, Nigeria etc. Entrepreneurship is sine qua non to national development, poverty eradication and employment generation. It is the bedrock of any nation's industrialization. Entrepreneurial development is a catalyst for economic, social and industrial development. Small and Medium Enterprises (SMEs) in Nigeria lack knowledge of project management tools, methods and techniques. This result to failures of project delivering as a result of poor budgeting, specification and deadlines of projects initiated. The primary challenge of project management is to achieve all of the project goals and objectives while honouring the preconceived constraints. The primary constraints are scope, time, quality and budget. The secondary and more ambitious challenge is to optimize the allocation of necessary inputs and integrate them to meet pre-defined objectives.

Implementing project management allows organizations to be more efficient, effective, and competitive in a shifting, complex, and unpredictable environment [1]. Many project management studies investigate the critical success factors to projects [2-4] and project failures [5]. According to Turner and Muller defines project management an organization of human materials and financial resources in a novel way, to undertake a unique scope of work, of given specification, within constraints of cost and time, defined by quantitative and qualitative objectives so as to achieve a beneficial change. Project Management is the discipline of planning, organizing, motivating, and controlling resources to achieve specific goals. A project is a temporary endeavour with a defined beginning and end (usually time-constrained, and often constrained by funding or deliverables), undertaken to meet unique goals and objectives, typically to bring about beneficial change or added value [6]. The temporary nature of projects stands in contrast with business as usual (or operations), which are repetitive, permanent, or semi-permanent functional activities to produce products or services. In practice, the management of these two systems is often quite different, and as such requires the development of distinct technical skills and management strategies.

\section{SMEs: Project management problems in Nigeria}

Projects can include innovations, new product development, product, process improvement and implementations of new processing technology. Implementing project management allows Small and Medium Enterprises (SMEs) to be more-efficient, effective, and competitive in a shifting, complex, and unpredictable environment. Project management problems associated with SMEs in Nigeria includes Organizational Structure, Finance, planning, Project Management Knowledge and Environment.

Project involve multiple and interwoven tasks that must be performed under a set of conditions. Scheduling these tasks is a critical component of project planning, execution, and control. Schedule overruns or delayed completion of projects is common experience in Nigeria.

Delays which can result in increased cost of projects can result from a variety of causes and may include both controllable and uncontrollable factors. Controllable factors could come from planning, estimates, resources, technologies, scheduling, management and control, client factors and so on [1,7-9].

\section{Organizational structure}

An important factor that relates to project success is organizational structure. Organizational structure refers to an organization's internal pattern of relationships, authority, and communication. Individual projects require varying mixes of personnel and knowledge resources, including cross-functional and cross organizational input. Also, organizational structure defines the relationship between the individual project manager's leadership style and the success of projects. Many SMEs in Nigeria are small business enterprises are controlled by their owners with no defined organisational structure and distinction between the ownership and control of the business [10]. 
Page 2 of 3

\section{Finance}

Small and Medium Enterprises in most cases do not have sufficient funds to undertake projects, support their businesses and ICT infrastructure [11-15]. Also, there are problems such as lack of finances to engage Project Management professional staff or experts to management projects, and inability to secure sufficient facilities from banks for projects due to unavailability of collateral securities.

\section{Project management knowledge}

Project management responsibilities include creating clear and attainable project objectives, building the project requirements, and managing the constraints of the project management triangle, which are cost, time, scope, and quality. Managers in SMEs in Nigeria do not have knowledge of the functionality of project management. Effective project management leadership has been suggested as an important success factor on projects while Dulewicz, 2008 state that there is a need to investigate the impact of the individual manager's leadership style on the success of their projects.

\section{Environment}

The general or macro environment incorporates wider factors in the market and society in which the organisation operates; industry structure, the national and international economy, law, politics, culture, technological development and natural resources. Nigerian environment has been characterized by epileptic power supply, insecurity, double taxation and frequent policy changes. This has impacted negatively on SMEs ability to manage projects.

\section{Scope of this Research}

This research examines the problems that confront SMEs to effectively manage projects. The research also examines the relationship between failures of SMEs and undertaken SMEs project uncertainties in Nigeria and proffers solutions to surmount the associated problems failures of SMEs and their undertaken projects.

\section{Research and Methodology}

The researcher applied convenient sampling namely the simple sampling technique in selecting SMEs in Nigeria and thus primary data is collected through structured questionnaire from the sample of 35 selected SMEs in Nigeria using the structured survey method. Primary data collected from respondents in were analyzed using percentage analysis method. The secondary data for the study was compiled from the reports of websites, journals, magazines and books. This study is limited to managers in 35 SMEs as respondents, a small sample size compared to the thousands of SMEs in Nigeria. However, the sample size of 35 respondents is sufficient to measure the impact of project management in SMEs in Nigeria. When working with small sample sizes Marcoulides and Saunders, recommend that a researcher should consider "the distributional characteristics of the data, potential for missing data, the psychometric properties of the variables examined, and the magnitude of the relationships considered before deciding on an appropriate sample size to use or to ensure that a sufficient sample is actually available to study the phenomenon of interest.

\section{Construct reliability and validity}

All constructs used in the study demonstrated adequate reliability with Cronbach's alpha scores well above the recommended cut off of 0.82 across all constructs. Composite reliabilities which are a more accurate measure of internal consistency because they avoid assumption of equal weighting of items were even higher.

\section{Findings and Discussions}

The values explained in Table 1 were greater than the recommended value of 0.5 . The square root of AVE for each construct was greater than construct's correlation other constructs, further demonstrating discriminant validity.

\begin{tabular}{|l|l|l|l|}
\hline Variable Name & Cronbach Alpha & Composite Reliability & Average Values \\
\hline Project interdependence & 0.74 & 0.85 & 0.66 \\
\hline Project Uncertainty & 0.72 & 0.83 & 0.62 \\
\hline Relational Capital & 0.76 & 0.85 & 0.66 \\
\hline Internal Knowledge Integration & 0.91 & 0.94 & 0.80 \\
\hline External Knowledge Integration & 0.72 & 0.84 & 0.65 \\
\hline
\end{tabular}

Table 1: Reliability and validity estimates for the study variables.

\begin{tabular}{|c|c|c|c|c|c|c|c|c|c|c|c|}
\hline $\mathbf{S} / \mathbf{N}$ & Variable & Mean (SD) & 1 & 2 & 3 & 4 & 5 & 6 & 7 & 8 & 9 \\
\hline \multirow[t]{2}{*}{1} & \multirow[t]{2}{*}{ Project Duration } & 130.26 & \multirow[t]{2}{*}{ na } & & & & & & & & \\
\hline & & -80.24 & & & & & & & & & \\
\hline \multirow[t]{2}{*}{2} & \multirow[t]{2}{*}{ Team Size } & 150.28 & \multirow[t]{2}{*}{$0.20^{\star *}$} & \multirow[t]{2}{*}{ na } & & & & & & & \\
\hline & & -210.74 & & & & & & & & & \\
\hline
\end{tabular}




\begin{tabular}{|c|c|c|c|c|c|c|c|c|c|c|c|}
\hline \multirow[t]{2}{*}{3} & \multirow[t]{2}{*}{ Member experience } & 90.7 & \multirow[t]{2}{*}{0.1} & \multirow[t]{2}{*}{0.07} & \multirow[t]{2}{*}{ na } & & & & & & \\
\hline & & -40.29 & & & & & & & & & \\
\hline \multirow[t]{2}{*}{4} & \multirow[t]{2}{*}{ Project interdependence } & 40.38 & \multirow[t]{2}{*}{0.04} & \multirow[t]{2}{*}{0.05} & \multirow[t]{2}{*}{0.81} & & & & & & \\
\hline & & -20.25 & & & & & & & & & \\
\hline \multirow[t]{2}{*}{5} & \multirow[t]{2}{*}{ Project Uncertainty } & 40.52 & \multirow[t]{2}{*}{-0.11} & \multirow[t]{2}{*}{0.1} & \multirow[t]{2}{*}{-0.1} & \multirow[t]{2}{*}{-0.1} & \multirow[t]{2}{*}{0.78} & & & & \\
\hline & & -20.16 & & & & & & & & & \\
\hline 6 & Relational capital & $\begin{array}{l}40.01 \\
-20.1\end{array}$ & 0.1 & 0.09 & 0.02 & $0.26^{\star *}$ & $-0.11^{*}$ & $0.26^{* *}$ & 0.86 & & \\
\hline \multirow[t]{2}{*}{7} & \multirow[t]{2}{*}{ Internal knowledge integration } & 60.27 & \multirow[t]{2}{*}{$0.13^{*}$} & \multirow[t]{2}{*}{0.02} & \multirow[t]{2}{*}{-0.05} & \multirow[t]{2}{*}{$0.32^{* \star}$} & \multirow[t]{2}{*}{$-0.25^{* *}$} & \multirow[t]{2}{*}{$0.33^{* *}$} & \multirow[t]{2}{*}{$0.57^{* *}$} & \multirow[t]{2}{*}{$0.80^{*}$} & \\
\hline & & -20.22 & & & & & & & & & \\
\hline \multirow[t]{2}{*}{8} & \multirow[t]{2}{*}{ External knowledge integration } & 50.42 & \multirow[t]{2}{*}{0.06} & \multirow[t]{2}{*}{0.04} & \multirow[t]{2}{*}{-0.06} & \multirow[t]{2}{*}{$0.36^{* *}$} & \multirow[t]{2}{*}{$-0.28^{* *}$} & \multirow[t]{2}{*}{$0.31^{* *}$} & \multirow[t]{2}{*}{$0.33^{* *}$} & \multirow[t]{2}{*}{$0.57^{* *}$} & \multirow[t]{2}{*}{0.8} \\
\hline & & -20.28 & & & & & & & & & \\
\hline
\end{tabular}

Table 2: Descriptive statistics and correlation.

Internal knowledge integration had a negative correlation with project uncertainty $(\mathrm{r}=.25, \mathrm{p}<0.01)$, and a positively correlation with project interdependence $(r=0.32, p<0.01)$ and with project duration $(r$ $=0.13, \mathrm{p}<0.01)$ as mentioned in Table 2 . Also, team size had a positive correlation with positive duration $(\mathrm{r}=0.20, \mathrm{p}<0.01)$.

\section{Managerial Implications}

- Managers of SMEs in developing countries should be aware of the high rates of project failures and project uncertainties.

- This research has shown that some of the reasons of project failures include inadequate planning and lack of knowledge of project management.

- Team size and member experience impacted positively on the successful completion of projects.

- Project successes can enhance the sustainability of SMEs.

- SMEs can overcome these challenges through adequate training of personnel in project management, recruitment of a qualified Project Manager.

- More importantly, projects that are conceptualized and executed should be according to the capacity of the SMEs.

\section{Conclusion}

SMEs engage in projects which includes innovations, new product development, product, process improvement and implementations of new processing technology. SMEs in Nigeria face challenges that hinder their projects such as Organizational Structure, Finance, Project Management Knowledge and Environment. Small and Medium Enterprises in most cases do not have sufficient funds to support ICT infrastructure, lack of finances to engage Project Management professional staff or experts to management projects, and inability to secure sufficient facilities from banks for projects due to unavailability of collateral securities. Successful projects require varying mixes of personnel and knowledge resources, including cross-functional and cross organizational input.

\section{References}

1. Ika LA (2009) Project success as a topic in project management journals. Project Management Journal 40: 6-19.

2. Belout A (1998) Effects of human resource management on project effectiveness and success: toward a new conceptual framework. International Journal of Project Management 16: 21-26.

3. Baccarini D (1999) The logical framework method for defining project success. Project Management Journal 30: 25-32.

4. Jugdev K, Müller R (2005) A Retrospective Look at Our Evolving Understanding of Project Success. IEEE Engineering Management Review 34: 110-127.

5. Dilts DM, Pence KR (2005) Impact of role in the decision to fail: An exploratory study of terminated projects. Journal of Operations Management 24: 378-396.

6. Pinto JK (2007) Project Management: Achieving Competitive Advantage. Pearson Education, NJ.

7. Cooke-Davis $\mathrm{T}$ (2002) The real success factors on projects. International Journal of Project Management 20: 189-190.

8. Kappelman L, Mckeeman R, Zhang L (2006) Early warning signs of IT projects failure: The dominant dozen. Information Systems Management 23: $31-36$.

9. Cerpa N, Verner J (2009) Why did your project fail? Communications of AGM 52: 130-134.

10. Abor J (2007) Corporate governance, ownership structure and performance of SMEs in Ghana: Implications for financing opportunities. The International Journal of Business in Society 7: 288-300.

11. Tung R, Aycan Z (2008) Key success factors and indigenous management in SMEs in emerging economies. Journal of World Business 43: 381-384.

12. Luthans F, Davis TRV (1982) An Idiographic Approach to Organizational Behavior research: The Use of Single Case Experimental Designs and Direct Measures. Academy of Management Review 7: 380-391.

13. Marcoulides GA, Saunders C (2006) PLS: A Silver Bullet? MIS Quarterly pp: 30.

14. Nelson RR (2007) I.T project management: infamous failures, classic mistakes, and best practices. MIS Quarterly Executive 6: 67-78.

15. Muller R, Turner R (2007) Matching the project manager's leadership style to project type. International Journal of Project Management 25: 21-32. 